\title{
Physical Fitness Component Profiles of Futsal Team Members of Universitas Padjadjaran in November 2011
}

\author{
R. Muhammad Tanri Arrizasyifaa, ${ }^{1}$ Juliati, $^{2}$ Vitriana $^{3}$ \\ ${ }^{1}$ Faculty of Medicine Universitas Padjadjaran, ${ }^{2}$ Department of Physiology, Faculty of Medicine \\ Universitas Padjadjaran, ${ }^{3}$ Department of Physical Medicine and Rehabilitation Faculty of \\ Medicine Universitas Padjadjaran/Dr. Hasan Sadikin General Hospital Bandung
}

\begin{abstract}
Background: To be a good athlete, an athlete needs to possess good predominant components of physical fitness. Futsal Team of Universitas Padjadjaran has never won any competition. This study was conducted to identify the predominant component profiles of physical fitness of Futsal Team members of Universitas Padjadjaran. The predominant component profiles were classified based on the Indonesian National Sport Committee (KONI) standard.

Methods: This study was carried out at the Faculty of Medicine Student Center of Universitas Padjadjaran in November 2012. Twenty two members of the Futsal Team were enrolled as subjects of the study. The study used the step test to examine aerobic endurance; the leg dynamometer to measure leg muscle strength; the squat jump test to test the leg muscle endurance; the vertical jump test to measure leg muscle power; and the sit and reach test to measure lower extremity flexibility. The data collected were analyzed using percentage.

Results: Leg muscle strength was mostly in the fair category (95\%). Leg muscle power was mostly in the good category (41\%). Leg muscle endurance was mostly in the good category (82\%). Leg flexibility was mostly in the excellent category (91\%) and aerobic endurance was mostly in the good category (41\%).

Conclusions: Only several members of Universitas Padjadjaran Futsal Team have an excellent physical fitness profile. Most of the members fell into the fair and good category. [AMJ.2015;2(3):440-7]
\end{abstract}

Keywords: Aerobic endurance, flexibility, futsal, muscle endurance, muscle power

\section{Introduction}

Sport has become an important part in people's lives. People do sport for various purposes. It can be a means of recreation, maintenance or improvement of health, education, and also a means of achievement. ${ }^{1,2}$

Futsal is a popular sport, including on university and college level. In order to be capable for accomplishing good achievements, it is necessary for athletes to possess good predominant components of physical fitness. The predominant components of physical fitness for futsal players are muscle strength, muscle endurance, muscle power, flexibility, and aerobic endurance. ${ }^{3}$

The Universitas Padjadjaran Futsal Team has been active in recent years by participating in various competitions. However, up to now, the team has never won any competition.

This study was undertaken to identify the profile of physical fitness components of the Universitas Padjadjaran Futsal Team which will be classified based on the Indonesian National Sport Committee (KONI) standard.

\section{Methods}

This study was carried out at the Faculty of Medicine Student Center Padjadjaran University in November 2012. Twenty two members of the Futsal Team were enrolled as subjects of the study.

The subjects received explanation about the study before it was conducted. It was confirmed that the subjects would not perform

Correspondence: R Muhammad Tanri Arrizasyifaa, Faculty of Medicine, Universitas Padjadjaran, Jalan Raya BandungSumedang Km.21, Jatinangor, Sumedang, Indonesia, Phone: +6285722519696 Email: arrizasyifaa@gmail.com 
any strenuous activities two days before the test and have enough sleep ( $\geq 7$ hours) the night before the data collection day.

The subjects were weighed with weight scales and their heights were measured by a height gauge. Resting pulse was calculated, and systolic and diastolic blood pressures at rest were measured using a sphygmomanometer. The subjects then warmed up and stretched for 15 minutes. Afterward, assisted by a standardized examiner team, the measurement of predominant physical components was executed in the following order: Astrandrhyming step test was performed to examine aerobic endurance; a leg dynamometer was used to measure lower extremity muscle strength; the squat jump test was performed to test the endurance of leg muscle; vertical jump test was performed to measure power of the lower leg muscles; and sit and reach test was performed to measure lower extremity flexibility.4 Then, the results were compared to the Indonesian National Sport Committee Standard. Next, data were analyzed using percentage.

\section{Results}

Out of 22 participants, 95\% had fair category of muscle strength, $41 \%$ had good category of muscle power, followed by very good and excellent ( $18 \%$ and $5 \%$, respectively).

Moreover, $82 \%$ of the participants had good category of muscle endurance, $91 \%$ had excellent flexibility and only half of them had good and excellent durability (41\% and $5 \%$, respectively).

\section{Discussion}

Universitas Padjadjaran Futsal Team Members have leg muscle strength that is classified into the fair and good categories with the average value of 104.56. This shows that the leg muscle strength training that has been performed so far was sufficient. In order to achieve better scores, it is preferable to execute isokinetic contraction on muscle strength training exercises. Isokinetic contraction exercise is proven to be more effective to strengthen muscle, compared to isometric contraction. ${ }^{5}$

Moreover, they had leg muscle explosive power that varies with the average value of 54.64. This indicated that exercise which has been carried out was not in accordance with the needs of the athletes. Referring to literatures, it states that muscle power is influenced by strength and speed. Even though muscle strength of the futsal athletes fall into the category of fair and good, the varying explosive power found among the team members confirm that there is another predominant component of physical fitness which is also influential. These results illustrate that a combination of exercises are needed to form good explosive power of

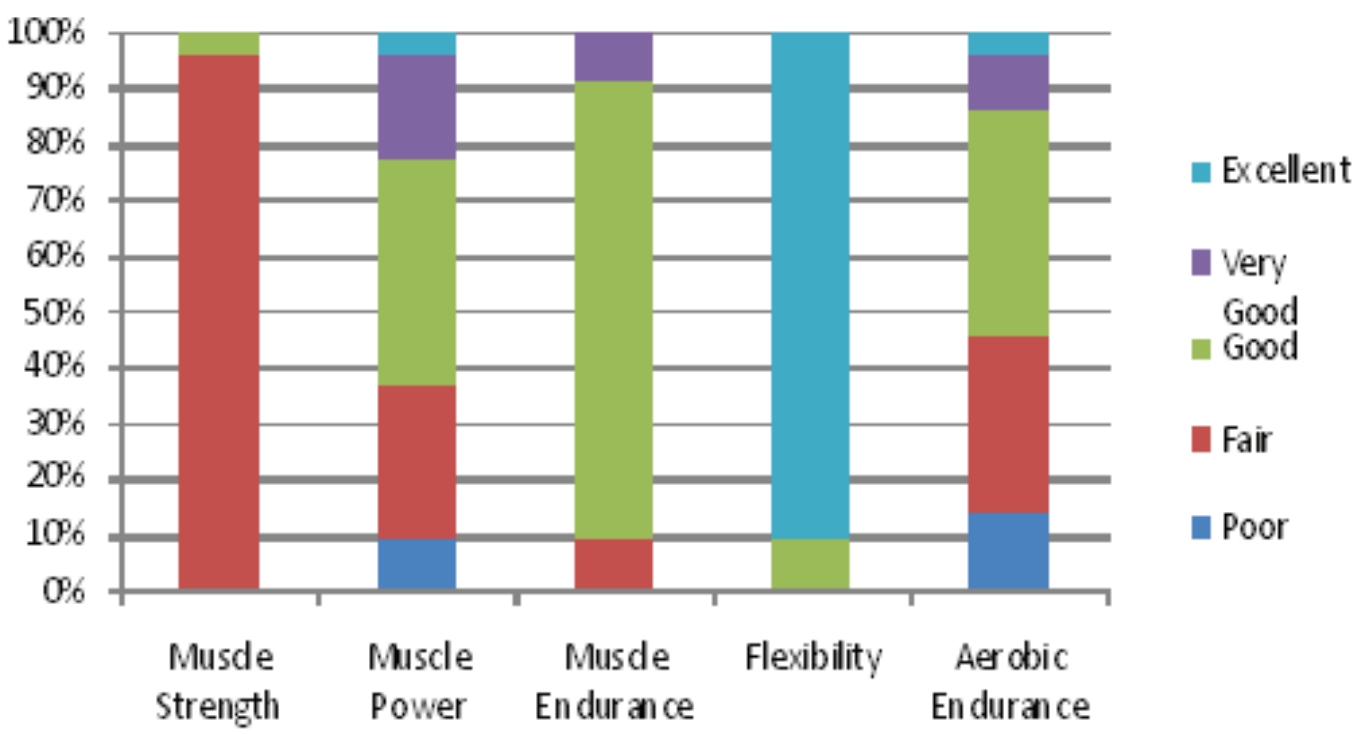

Figure 1 Profile of Physical Fitness Components of Universitas Padjadjaran Futsal Team 
athletes' muscles.,

The majority of the Futsal Team members' leg muscle endurance is good, with an average value of 59.50. Some fall into the category of fair and very good, thus indicating that the allotted trainings were adequate in meeting the needs.

The limb flexibility of the Futsal Team members is almost entirely excellent with an average value of 35.98. Only a small part is in the good category. This shows that the portion of the exercise to increase flexibility is already very adequate.

Aerobic metabolism is the primary energy system in soccer and highly important to a player's recovery during a game. ${ }^{7}$ Figure 1 , shows that the aerobic endurance of Universitas Padjadjaran Futsal Team members vary with the average value of 46.55. In general, the team falls under the category of fair and good. Furthermore, a small part of athletes are very good and excellent, but there are also athletes in the poor category. This shows that the allotted portion of practice has not fulfilled the needs of all athletes. Nonetheless, poor value can also be caused by genetic factors and respiratory issues. ${ }^{8,9}$

The type of exercise that is recommended to improve physical fitness is aerobic which may activate at least $40 \%$ of the body muscles simultaneously within 30-60 minutes. The exercise should be done 3-5 times in a week.2 Based on observations, Universitas Padjadjaran Futsal Team members currently regularly practice two times a week but with an uncertain duration of aerobic exercise.

The poor measurement results of some athletes may also be caused by the duration of exercise they have endured and its propriety with the training periodization system. Within the periodization training, it is recommended that the exercises are done for at least 4 months. Muscular strength, general endurance, and flexibility must be trained during the first 6 weeks. Meanwhile, the explosive muscles power should be trained on week 7 to week 12 and the muscular endurance on week 13 to week-to-16. ${ }^{2}$

Limitation of this study is subjects are not distinguished by length of training while differences in length of training course can affect the test results. Limitation in terms of the team's physical examination may also lead to interobserver bias. In addition, this study also did not pay attention to other factors that can influence the results, such as nutritional factors. ${ }^{10}$

It can be concluded that not all membersof Universitas Padjadjaran Futsal Team have an excellent physical fitness profile. Most of them, fall into fair and good category.

\section{References}

1. Giriwijoyo HYSS, editor. Olahraga dan olahraga kesehatan. 7th ed. Bandung: FPOK UPI; 2007.

2. Purba A. Kardiovaskular dan faal olahraga. Bandung: Bagian Ilmu Faal/Faal Olahraga Fakultas Kedokteran Universitas Padjadjaran; 2006.

3. FIFA. Futsal. [Cited 2012 November 12]; Available from: www.fifa.com

4. Purba A. Prosedur pelaksanaan tes kondisi fisik/tes fisiologi atlet. In: Albert Hutapea, Leonardo Lubis, Aep Kusnandar, editors. Bandung: Perhimpunan Ahli Ilmu Faal Olahraga Indonesia (PAIFORI); 2011.

5. Harsono. Coaching dan aspek-aspek psikologis dalam coaching. Jakarta: P2LPTK; 1988.

6. Wilmore JH, Costill DL. Physiology of sport and exercise. 10th ed. Illinois: Human Kinetics; 1994.

7. Reilly T, Bangsbo J, Franks A. Anthropometric and physiological predispositions for elite soccer. J Sports Sci. 2000;18(9):669-83.

8. Bompa TO, Haff GG. Periodization: theory and methodology of training. 5th ed. Illinois: Human Kinetics; 2009.

9. Fox EL, Foss ML, Keteyian SG. Physiological basis for exercise and sport. 6th ed. New York: McGraw-Hill; 1998.

10. Hinckson EA, Dickinson A, Water T, Sands M, Penman L. Physical activity, dietary habits and overall health in overweight and obese children and youth with intellectual disability or autism. Res Dev Disabil. 2013; 34(4):1170-8. 


\title{
Characteristics and Predisposing Factors of Bacterial Corneal Ulcer in the National Eye Center, Cicendo Eye Hospital, Bandung from January to December 2011
}

\author{
Astrid Maharani Putri, ${ }^{1}$ Susi Heryati, ${ }^{2}$ Nursiah Nasution ${ }^{3}$ \\ ${ }^{1}$ Faculty of Medicine Universitas Padjadjaran, ${ }^{2}$ Department of Ophthalmology Faculty of Medicine \\ Universitas Padjadjaran/National Eye Center Cicendo Eye Hospital Bandung, ${ }^{3}$ Department of \\ Anatomy and Cell Biology Faculty of Medicine Universitas Padjadjaran
}

\begin{abstract}
Background: Corneal ulcer is an emergency condition in ophthalmology, causing visual impairment, mostly by bacterial infection with rapid pathogenesis. The aim of this study was to discover the characteristics of bacterial corneal ulcer patients in the National Eye Center, Cicendo Eye Hospital, Bandung..

Methods: A total of 99 medical records consisted of patients diagnosed with bacterial corneal ulcer were selected in this descriptive study. The clinical patterns and predisposing factors of the patients were analyzed. The study also identified the pathogenic bacteria of the cases. This study was carried out in the National Eye Center, Cicendo Eye Hospital, Bandung from January to December 2011 Clinical patterns. The collected data were analyzed and presented in frequency tabulation.

Results: The male to female ratio was $2: 1$, with the average age of 44.4 years. The most common presenting symptom was eye pain (70.7\%). Most patients came with decreased visual acuity that was categorized as (near-) blindness (78.8\%) and the location of the ulcer was in central area of the cornea (56.5\%). The most common predisposing factor was ocular trauma (74.7\%) that was caused by exposed to plants. Singlebacterial infection (67.7\%) was predominant, with 56 cases (56.6\%) of Gram-positive cocci infection.

Conclusions: Bacterial corneal ulcer contributes to $48.8 \%$ of all microbial corneal ulcers. Most patients came with mild condition, centralized location, and poor visual function. The common predisposing factor was trauma associated with exposed to plants.
\end{abstract}

Keywords: Bacterial infection, corneal ulcer, trauma, visual acuity

\section{Introduction}

Corneal ulcer is a pathologic condition that develops in cornea, which is characterized by suppurative infiltrate and discontinuity of corneal tissue starting from epithelium to stroma. Corneal ulcer is mostly caused by infection, with $90 \%$ of the corneal infection caused by bacteria. Bacterial ulcers tend to have a more rapid pathogenesis. Corneal ulcer is also an emergency condition in ophthalmology because it can form turbidity at the cornea. This may lead to visual impairment and even blindness. ${ }^{1-4}$

In many parts of the world, corneal ulcer is one of the major causes of blindness. ${ }^{5-9}$ Dhakwa et al. ${ }^{5}$ reported that out of 414 cases, bacterial cultures were positive in 300 cases.
Pure bacterial growth was present in 121 of all corneal ulcer cases, with single-bacterial infection more dominant than multiplebacterial infection. This study was intended to collect data related to epidemiological features, predisposing factors, causative microorganisms, and clinical manifestations for cases of bacterial corneal ulcers, which aimed to provide background information of bacterial corneal ulcers.

\section{Methods}

The descriptive study was conducted in the National Eye Center Cicendo Eye Hospital Bandung in Augusts to November 2012. Medical records were reviewed for 203 patients with corneal ulcers who were treated

Correspondence: Astrid Maharani Putri, Faculty of Medicine, Universitas Padjadjaran, Jalan Raya Bandung-Sumedang Km.21, Jatinangor, Sumedang, Indonesia, Phone: +6287877558216 Email: a.maharaniputri@gmail.com 
or hospitalized at the Indonesian National Eye Center (INEC) - Bandung Cicendo Eye Hospital from 1st of January to 31st of December 2011.

Medical records were carefully examined; cases with viral or fungal infections and incomplete medical records were excluded, resulting in 99 patients with bacterial corneal ulcer out of the total 203 patients with corneal ulcer. Medical records were reviewed to determine prominent features including sex, age, symptoms, visual acuity, predisposing factors, degree of severity, pathogenic bacteria, and location of ulcer. All these patients' data were recorded in Microsoft Office Excel and then analyzed with SPSS version 15.0.

\section{Results}

The epidemiological characteristics' distribution of patients diagnosed with bacterial corneal ulcer is presented in Table 1. The male to female ratio was 2:1. The average age of all patients was 44.4 years. Symptoms were also reviewed; the most frequent presenting symptom was eye pain, which was complained by 70 patients $(70.7 \%)$ out of the total bacterial corneal ulcer patients. The next most frequent symptoms were red eye (61 patients; 61.6\%) and white spot at black part of the eye (50 patients; $50.5 \%$ ). Most of the patients came with (near-) blindness (78 patients; 78.8\%).

Predisposing factors were identified for 92 patients (92.9\%). The most common predisposing factor for bacterial corneal ulcer was ocular trauma $(74.7 \%$ ) (Table 2)

Corneal scrapping had been performed for patients with suspected microbial corneal ulcer. The result of microbiological examination with Gram staining was written in the medical records. Infection by single-bacteria $(67$ patients; $67.7 \%$ ) was predominantly found in patients with bacterial corneal ulcer than with multiple-bacteria (32.3\%). Most of the cases of single-bacterial infection were caused by Gram-positive cocci (Table 3)

Table 1 Characteristics of Patients with Bacterial Corneal Ulcer

\begin{tabular}{|c|c|}
\hline \multirow{2}{*}{ Characteristic } & Bacterial Corneal Ulcer \\
\hline & $\mathrm{n}(\%)$ \\
\hline \multicolumn{2}{|l|}{ Sex } \\
\hline Male & $66(66.7)$ \\
\hline Female & $33(33.3)$ \\
\hline Age, y,ears, mean (SD) & $44.4(16.3)$ \\
\hline \multicolumn{2}{|l|}{ Symptoms } \\
\hline Eye pain & $70(70.7)$ \\
\hline Red eye & $61(61.6)$ \\
\hline White spot at black part of the eye & $50(50.5)$ \\
\hline Decreased in vision & $35(35.4)$ \\
\hline Watery eye & $29(29.3)$ \\
\hline Propped eye & $16(16.2)$ \\
\hline Exudate & $14(14.1)$ \\
\hline Itchy eye & $12(12.1)$ \\
\hline Swollen eye & $7(7.1)$ \\
\hline Headache & $7(7.1)$ \\
\hline Photophobia & $5(5.1)$ \\
\hline \multicolumn{2}{|l|}{ Visual acuity } \\
\hline (Near-) normal vision & $5(5.1)$ \\
\hline Low vision & $16(16.2)$ \\
\hline (Near-) blindness & 78 (78.8) \\
\hline
\end{tabular}


Astrid Maharani Putri, Susi Heryati, Nursiah Nasution: Characteristics and Predisposing Factors of Bacterial 445 Corneal Ulcer in the National Eye Center, Cicendo Eye Hospital, Bandung from January to December 2011

Table 2 Predisposing Factors of Patients with Bacterial Corneal Ulcer

\begin{tabular}{|c|c|}
\hline \multirow{2}{*}{ Predisposing Factors } & Bacterial Corneal Ulcer \\
\hline & n $(\%)$ \\
\hline Trauma: & $74(74.7)$ \\
\hline Plant matter & $26(26.3)$ \\
\hline Dust & $14(14.1)$ \\
\hline Soil & $11(11.1)$ \\
\hline Wood & $6(6.1)$ \\
\hline Stone & $5(5.1)$ \\
\hline Metal & $4(4.0)$ \\
\hline Insect & $3(3.0)$ \\
\hline Unidentified source & $5(5.1)$ \\
\hline Chronic ocular and systemic disorder: & $12(12.1)$ \\
\hline Keratitis & $3(3.0)$ \\
\hline Pterigium & $2(2.0)$ \\
\hline Endophtalmitis & $2(2.0)$ \\
\hline Diabetes mellitus & $2(2.0)$ \\
\hline Panophtalmitis & $1(1.0)$ \\
\hline Blepharitis & $1(1.0)$ \\
\hline Trichiasis & $1(1.0)$ \\
\hline Contact-lens wear & $4(4.0)$ \\
\hline Recent ocular surgery & $2(2.0)$ \\
\hline Unknown & $7(7.1)$ \\
\hline
\end{tabular}

The severity cases in this study was based on Jones', the most prominent degree of severity criteria of all patients with bacterial corneal ulcer was mild, as presented in Table 4.

The majority of bacterial corneal ulcer patients were (near-) blindness with the location of ulcer at the central cornea (53 patients; 53.5\%). However, of all cases with low vision $(n=16), 3$ cases were at the central cornea, 10 cases were at paracentral, and others were at peripheral. Of all cases with (near-) normal vision $(n=5)$, no cases were identified at the central cornea. The distribution of visual acuity and ulcer location is presented in Table 5.

Discussion

Table 3 Pathogenic Bacteria of Patients with Bacterial Corneal Ulcer

\begin{tabular}{lc}
\hline \multirow{2}{*}{ Bacteria } & Bacterial Corneal Ulcer \\
\cline { 2 - 2 } & $\mathrm{n}(\%)$ \\
\hline Single-bacteria & $67(67.7)$ \\
Gram-positive cocci & $56(56.6)$ \\
Gram-negative cocci & $1(1.0)$ \\
Gram-negative baccili & $10(10.1)$ \\
Multiple-bacteria & $32(32.3)$ \\
\hline
\end{tabular}


Table 4 Severity of Patients with Bacterial Corneal Ulcer

\begin{tabular}{lcc} 
& \multirow{2}{*}{ Severity } & Bacterial Corneal Ulcer \\
\cline { 2 - 2 } & $\mathbf{n}(\%)$ \\
\hline Mild & $51(51.5)$ \\
Moderate & $16(16.2)$ \\
Severe & $32(32.3)$ \\
\hline
\end{tabular}

Corneal ulcer is an ophthalmic emergency requiring immediate diagnosis and treatment, especially bacterial corneal ulcer because of its rapid pathogenesis. Diagnosis of corneal ulcer can be established by clinical examinations, whereas diagnosis of its etiology cannot be established only by clinical manifestations. Diagnosis of etiology depends on laboratory examinations, like smears and cultures from direct scrapes of the corneal ulcer. The success of its treatment and prognosis depends on the appropriate diagnosis, etiology, and degree of severity. ${ }^{1,7,10,11}$ Knowing the characteristics of patients with bacterial corneal ulcer including predisposing factors, etiology, and degree of severity may help in establishing diagnosis and treatment appropriately and promptly.

In this study, the incidence of bacterial corneal ulcer was more predominant in male $(66.7 \%)$ than female $(33.3 \%)$. This finding is similar to other studies which have been conducted in Indonesia and other countries. For example, in the studies in Dr. Sardjito Hospital $^{5}$, in $\mathrm{Nepal}^{7}$, and in Taiwan ${ }^{12}$, the majority of bacterial corneal ulcer patients were male. This may occur because male tends to have more outdoor activities like working, or those with certain occupations that puts them at high-risk locations for ocular trauma, i.e farmers and laborers. ${ }^{7,9}$

The average age of all patients was 44.4 years. This finding is similar to other studies. Fong et al. ${ }^{12}$ reported in his study in Taiwan during 1992-2001 that the mean age of all patients was 40.7 years. Additionally, Jeng et al. ${ }^{13}$ also reported in his study in Northern California during 1998-1999 that the mean age was 42.8 years. ${ }^{12,13}$

According to the literatures, symptoms of bacterial corneal ulcer are decreased vision, red eye, photophobia, eye pain, and exudates. ${ }^{3,14}$ In this study, most of the symptoms found were similar to the literature, with the most frequent presenting symptom was eye pain $(70.7 \%)$.

Most of patients in this study came with poor visual function which was categorized as (near-) blindness (78.8\%). This finding is similar to the study conducted in Dr. Sardjito Hospital, stating that most of the patients came with visual acuity $<3 / 60$, which was categorized as blindness according to WHO standard definition. ${ }^{2,7}$

The most common predisposing factor was ocular trauma, particularly by plant. Based on the result of the study performed by Dhakhwa et al. ${ }^{5}$, cases of corneal ulcer in western Nepal frequently occurred as sequela of agricultural injury causing corneal abrasion. So this finding is similar to the studies mentioned previously.

Corneal ulcer due to single-bacterial infection is prominent, mainly by Grampositive cocci bacteria $(56.6 \%)$. This finding is also similar to other studies, as performed by Dhakhwa et al. ${ }^{5}$ in Western Nepal in 2007. The study reported that bacterial corneal ulcer was mostly caused by Gram-positive cocci single bacterial infection. ${ }^{5}$

According to Jones' Criteria, clinical degree of severity of corneal ulcer is graded as mild, moderate, or severe. Four essential aspects are required in assessing the severity, i.e ulcer size, ulcer depth, infiltrate, and scleral involvement ${ }^{15}$. Most of the patients came

Table 5 Visual Acuity and Ulcer location of Patients with Bacterial Corneal Ulcer

\begin{tabular}{lccc}
\hline \multirow{2}{*}{ Visual Acuity } & \multicolumn{3}{c}{ Ulcer Location } \\
\cline { 2 - 4 } & Central $\mathbf{n ( \% )}$ & Paracentral $\mathbf{n ( \% )}$ & Periphery n(\%) \\
\hline (Near-) normal vision & - & $4(4.0)$ & $1(1.0)$ \\
Low vision & $3(3.0)$ & $10(10.1)$ & $3(3.0)$ \\
(Near-) blindness & $53(53.5)$ & $20(20.2)$ & $5(5.1)$ \\
\hline
\end{tabular}


Astrid Maharani Putri, Susi Heryati, Nursiah Nasution: Characteristics and Predisposing Factors of Bacterial 447 Corneal Ulcer in the National Eye Center, Cicendo Eye Hospital, Bandung from January to December 2011

with mild severity (51.5\%), and this is similar to the study in Dr. Sardjito Hospital, as the tertiary eye care in D.I. Yogyakarta, reporting that patients mostly came with mild severity (43.9\%), followed by moderate $(31.6 \%)$ and severe $(24.7 \%)^{7}$

In this study, all of the ulcers located at the central cornea cause visual impairment and mostly cause (near-) blindness. This finding is similar to the literature stating that corneal ulcer is one of the emergency conditions in ophthalmology because cornea plays an important role in maintaining visual function, specifically as a refractive media which has optical properties (determined by its transparency, surface smoothness, contour and refractive index). If a turbidity is developed in the cornea, it will induce alteration in its optical properties and therefore interfere the entry of light, so it may cause impaired vision. ${ }^{1,4,16}$

There were some limitations in this study. This study was a cross-sectional retrospective study using secondary data; therefore, the quality of this research result totally depended on the quality of those data. Some data were incomplete, so they must be excluded.

In conclusion, the incidence of microbial corneal ulcer was 203 cases, with $48.8 \%$ was bacterial type. The characteristics of patients' bacterial corneal ulcer found in this study mostly occurred to male patients. They came with eye pain, history of ocular trauma mostly caused by plant, and caused by Gram-positive cocci bacterial infection. Most of the patients were diagnosed with mild severity, with central location, and poor visual function.

Despite these limitations, this research is considered to be useful as a basis of upcoming research and essential information for health workers and the society. According to these findings, it is recommended that visual acuity to be included as an additional aspect to assess the clinical severity of corneal ulcer.

\section{References}

1. Ilyas $\mathrm{S}$, editor. Ilmu penyakit mata. 3th ed. Jakarta: Balai Penerbit FKUI; 2005. p. 4-167.

2. Dijk Kv. Definition: visual impairment. 2012. [Cited 2012 May 14]. Available from: http://www.bpaindia.org/VIB\%20 Chapter-I.pdf.

3. Lang GK. Cornea. In: Lang GK, editor. Ophtalmology: a short textbook. Stuttgart:
Georg Thieme Verlag; 2000. p. 117-56.

4. Kumar A, Pandya S, Kavathia G, Antala S, Madan M, Jadvekar T. Microbial keratitis in Gujarat, Western India: findings from 200 cases. Pan Afr Med J. 2011;10:48.

5. Dhakhwa K, Sharma, Bajimaya S, Dwivedi AK, Rai S. Causative organisms in microbial keratitis, their sensitivity pattern and treatment outcome in western Nepal. Nepal J Ophtalmol. 2012;4(1):119-27.

6. Norina TJ, Raihan S, Bakiah S, Ezanee M, Liza-Sharmini AT, Wan Hazzabah WH. Microbial keratitis: aetiological diagnosis and clinical features in patients admitted to Hospital University Sains Malaysia. Singapore Med J. 2008;49(1):67-71.

7. Suhardjo, Widodo F, Dewi UM. Tingkat keparahan ulkus kornea di RS

8. Dr. Sardjito sebagai tempat pelayanan mata tersier. Medika. 2003;29(3):148-52.

9. Sinha R, Sharma N, Vajpayee RB. Corneal blindness-present status.. Cataract \& Refractive Surgery Today. 2005. [Cited 2012 May 14] Available from: http:// crstoday.com/2005/09/CRST1005_14. php/

10. Bangun CYY. Prevalensi kebutaan akibat kelainan kornea di Kabupaten Langkat (Thesis). Medan:University of Sumatera Utara; 2009.

11. Biswell R. Vaughan \& Asbury's General Ophtalmology. 16th Ed. New York:McGrawHill Medical; 2007.

12. Seal DV, Pleyer U. Ocular Infection. 2th ed. Boca Raton, Florida: CRC Press; 2008.

13. Fong CF, Tseng CH, Hu FR, Wang IJ, Chen WL, Hou YC. Clinical chracteristics of microbial keratitis in a University Hospital in Taiwan. Am J Ophtalmol. 2004;137(2):329-36

14. Jeng BH, Gritz DC, Kumar AB, Holsclaw DS, Porco TC, Smith SD, et al.. Epidemiology of ulcerative keratitis in Northern California. Arch Ophtalmol. 2010;128(8):1022-8

15. Mielke J. Cornea. In: Schlote T, Rohrbach J, Grueb M, Mielke J, editors. Pocket atlas of ophtalmology. New York: Thieme; 2006. p. 96-7.

16. Cokingtin CD, Hyndiuk RA. Bacterial keratitis. In: Tabbara KF, Hyndiuk RA, editors. Infections of the Eye. 2th ed. New York: Little, Brown and Company; 1996. p. 323-44.

17. Nishida T. Cornea. In: Krachmer JH, Mannis MJ, Holland EJ, editors. Cornea. 2th ed. New York: Elsevier Mosby; 2005. p. 3-22. 